\title{
Special Issue on Migration, Remittances, and Trade Agreements: An Introduction
}

\author{
Hiranya K. Nath \\ Sam Houston State University • Huntsville, Texas
}

The Journal of Business Strategies published a special issue on migration and remittances in Spring 2009 with six articles selected from the papers presented at the Conference on Regional Trade Agreements, Migration, and Remittances with Special Focus on CAFTA and Latin America held at the College of Business Administration, Sam Houston State University, in April 2008. The current special issue is a continuation of that effort and includes five more articles selected from the pool of papers presented at the conference. In addition to topics related to migration and remittances, this issue also includes articles on regional trade agreements (RTAs).

While migration of people across natural and man-made borders has remained a powerful force that contributes to the progress of human civilization, remittances - the transfers of money by migrants to family and friends left behind in their respective home countries - have been recognized as "the most tangible and ... the least controversial link between migration and development, having the potential to contribute significantly to poverty reduction and achievement of other UN Millennium Development Goals" (Irving et al, 2010). Although new migration flows fell during 2008-09 due to the global economic crisis, existing migrants were not returning even though the employment prospects have been bleak in many destination countries. In 2008 , officially recorded remittances to developing countries reached a higher-than-expected level of $\$ 338$ billion and it represented a growth of about 17 percent from $\$ 289$ billion in 2007. ${ }^{1}$ While South and East Asia witnessed a stronger-than-expected growth in remittance flows during 2008-09, Latin America and the Caribbean, Middle East, and North Africa experienced larger-than-expected declines. $^{2}$

In addition to migration and remittances, greater trade liberalization, particularly in developing countries, has become another hallmark of the current wave of globalization. However, the development of a multilateral trading system based on global free trade under the aegis of the General Agreements on Trade and Tariff (GATT)/World Trade Organization (WTO) has been extremely slow mainly due to the complexity of multilateral negotiations. This has given way to an unprecedented proliferation of Regional Trade Agreements (RTAs), which have become a prominent feature of the Multilateral Trading System (MTS). ${ }^{3}$ Almost every country is a part of one or more RTAs. Some 462 such agreements have been notified to the GATT/WTO up to February 2010 and 271 of them were in force. This trend is likely 
to continue as many more RTAs are currently under negotiations. Of these RTAs, Free Trade Agreements (FTAs) and partial scope agreements account for 90 percent, while customs unions (CUs) account for 10 percent. ${ }^{4}$

The rise of RTAs raises the time-honored question of whether these agreements help or hinder global trade liberalization. The classic analysis of the "trade diversion effect" (diversion of trade from a more efficient exporter towards a less efficient one by the formation of an FTA) by Jacob Viner (Viner 1950) was later extended to a full range of theoretically plausible effects of RTAs. The expositions on the implications of RTAs for global free trade are collectively known as the "stumbling bloc" or "building bloc" debate. ${ }^{5}$ In this debate, RTAs are "stumbling blocs" if they prevent or slow multilateral trade liberalization, while they are "building blocs" if they accelerate or at least do not hinder multilateralism. Numerous mechanisms have been presented in the literature to suggest that one or the other position is likely. The classic "trade diversion effect" as described above and the "trade creation effect" (more trade with the members of the RTA) are two such mechanisms extensively discussed in the literature.

\section{Migration and Remittances}

The first two articles in this special issue deal with topics related to international migration and remittances. While Borraz, Pozo, and Rossi examine the effect of migration on the subjective well-being of the family left behind by the migrants using data from Cuenca in Ecuador, Mamun and Nath analyze various aspects of workers' migration from Bangladesh and examine the economic impact of remittances received from these migrant workers.

\section{International Migration and Happiness}

Although the socio-economic effects of migration on the migrant-sending households have been extensively studied in the migration literature, the subjective well-being - the level of happiness - of the family members left behind by the migrant has not received much attention. One formidable issue is how to measure happiness. Recently, a few studies on this topic - based on survey data - have appeared in the literature. ${ }^{6}$ The article by Borraz, Pozo and Rossi belongs to this strand of the literature and aptly complements Cárdenas et al (2009). Using data on subjective well-being and migration of family members in Cuenca, one of the Ecuador's largest cities, they examine the impact of migration on the happiness of the family left behind. They find that although the heads of migrant-sending households 
seem to be less happy, after controlling for several socio-economic characteristics, they are no different from their counterparts of non-migrant households in their stated levels of happiness. That is, households that have experienced migration of their family members express the same level of happiness as those households that have no migrant members. The authors suggest that the remittances received by the households from the migrant members offset the decrease in their happiness level.

\section{Workers' Migration and Remittances in Bangladesh}

In the article by Mamun and Nath, the attention is directed to issues related to migration and remittances in Bangladesh, one of the poorest and most densely populated countries in the world. Bangladesh with a size of 1.5 percent of the U.S. in area and less than 1 percent in GDP has a population of more than 150 million, about half the size of the U.S. population. Constrained in many ways, this country has very few options left in its effort to achieve economic growth and development. No wonder that encouraging international migration to more prosperous countries has been a strategic policy tool for the government to contain the pressures in its ever-exploding labor market. Over a period of more than three decades since the mid-1970s, Bangladesh has sent more than 6.7 million workers to over 140 countries. Most of these workers temporarily migrate to work in Middle East and Southeast Asia. Note that if the people who migrated legally or illegally to other countries for permanent settlement were counted, the total number of Bangladeshi migrants would be much higher.

The mass movement of temporary migrant workers has not only eased some pressures on the over-burdened labor market in Bangladesh, but also the remittance transfers received from these migrant workers have significant economic impact in this country. These remittance transfers have reached a phenomenal level of over 10 billion US dollars in 2009, approximately 12 percent of GDP in Bangladesh. This paper analyzes trends and various other aspects of workers' migration and remittances in Bangladesh. It further discusses the micro and macroeconomic impacts of remittances. While most remittance transfers have been used by migrant-sending households for consumption, there is evidence to show that these transfers have helped reduce poverty in Bangladesh. The analysis presented in this paper also demonstrates that these remittances have significant impacts at the macroeconomic level. The empirical analysis indicates that these transfers have positive impact on the growth of industrial production and exports. 


\section{Regional Free Trade Agreements}

The last three articles focus on issues related to RTAs. The first two articles theoretically explore whether RTAs are the "building blocs" or the "stumbling blocs" for achieving the goal of global free trade under a multilateral trade arrangement. The last article empirically examines whether RTAs lead to more trade or less trade (that is, to a "trade creation effect" or a "trade diversion effect") and how they contribute to economic growth in 17 Latin American countries.

\section{Politics and Economics of Free Trade Agreements}

The article by Trupkin uses a political-economy framework to analyze whether regional free trade agreements are building blocs or stumbling blocs for multilateral trade liberalization. The paper builds on a framework originally introduced by Grossman and Helpman (995). The aim of their model was to explain the viability of FTAs between two countries when special interest groups - the lobbies - make political campaign contributions to influence trade policies. The author extends the model to a three-country setting to analyze whether FTAs are "building blocs" or "stumbling blocs." This paper uses a specific example to show that under certain conditions FTAs are only partial "building blocs" for global trade liberalization.

\section{Implications of a South-South Customs Union}

Following the failure of multilateral trade negotiations at the Cancun meeting and the Doha Round of the WTO, developing countries have pursued an alternative in so-called "south-south" trade agreements. Since these agreements lead to trade diversion from efficient north (developed) countries to less efficient south (developing) partners, there have been widespread concerns regarding their welfare implications. Using a three country oligopoly model of trade, the article by Nath and Yildiz first examines statically the implications of a south-south $\mathrm{CU}$ on the pattern of tariffs and welfare. The authors find that south countries always have incentives to form a $\mathrm{CU}$ that reduces the welfare of the north country. Moreover, when south firms are sufficiently inefficient relative to north firms, a south-south CU leads to a large trade diversion effect and reduces world welfare. They further show that, in a repeated interaction model, free trade is less likely to be sustainable under the south-south $\mathrm{CU}$ relative to no agreement. 


\section{Implications of Trade Agreements in Latin America}

Using data for a sample of 17 Latin American countries for the period 19502004, Barboza and Trejos examine the effects of Preferential Trade Agreements (PTAs) and GATT/WTO membership on economic growth. Their results indicate that the proliferation of bilateral and multilateral regional and extra regional trade agreements has not led to faster economic growth. However, they find that PTAs and WTO membership have a weak positive effect on trade openness. Furthermore, after controlling for capital, labor force, and trade openness, PTAs and WTO membership do not have any direct effect on economic growth. These results are robust to both static and dynamic model specifications.

\section{Notes}

1. See Irving et al. (2010)

2. See Ratha et al (2009).

3. RTAs are preferential trade agreements (PTAs) that may take one of the following forms:

1. A Free Trade Agreement (FTA) is an agreement between two or more countries that have eliminated tariffs and other trade restrictions on most (if not all) goods and services traded between them.

2. A Customs Union (CU) is a group of two or more countries that have an FTA and that also apply a common external tariff on goods and services from non-members.

3. A regional economic integration agreement is the next step: it can include the free movement of capital as well as goods and services, a common currency, and a common economic policy.

4. See WTO (2010).

5. For a detailed discussion on the debate, see Panagariya (1999) or Bhagwati( 2008).

6 Cárdenas et al. (2009), published in this journal is an example. 


\section{References}

Cárdenas, M., Di Maro, V., \& Sorkin, I. (2009). "Migration and life satisfaction: Evidence from Latin America." Journal of Business Strategies, Vol. 26, No. 1, $9-34$.

Grossman, G., \& Helpman, E. (1993). "The politics of free-trade agreements." NBER Working Paper, No. W4597.

Irving, J., Mohapatra, S., \& Ratha, D. (2010). "Migrant remittance flows: Findings from a global survey of central banks." World Bank Working Paper 194. Washington: The World Bank.

Panagariya, A. (1999). "The regionalism debate: An overview." The World Econo$m y$, Vol. 22, No. 4, 455-476.

Ratha, D., Mohapatra, S., \& Silwal, A. (2009). "Migration and remittance trends 2009: A better-than-expected outcome so far, but significant risk ahead." Migration and Development Brief 11. Washington: The World Bank.

Viner, J. (1950). The customs union issue. New York: Carnegie Endowment for International Peace.

World Trade Organization (WTO). 2010. Regional trade agreements, http://www. wto.org/english/tratop_e/region_e/region_e.htm.

\section{Biographical Sketch of Author}

Hiranya K. Nath is an Associate Professor of Economics at Sam Houston State University. He has published on inflation and relative price behavior, the growth of transition economies of Central and Eastern Europe, the growth of Bangladesh, and information economy in refereed journals including Applied Economics, Applied Economics Letters, Applied Financial Economics Letters, California Management Review, Comparative Economic Studies, Economics Letters, Journal of International Trade \& Economic Development, Journal of Macroeconomics, Journal of Money, Credit and Banking, and Review of Development Economics. He earned his Ph.D. in Economics from Southern Methodist University, Dallas (TX). 